\title{
Relationship between Transformational Leadership, Compensation, and Organizational Climate with Teachers' Performance
}

\author{
Mohamad Hisyam; Nyoman Sridana; Untung Waluyo
}

Master Program of Administration Education, Mataram University, Indonesia

http://dx.doi.org/10.18415/ijmmu.v6i6.1218

\begin{abstract}
Efforts to improve school quality are carried out by increasing discipline, motivation, job satisfaction, teacher performance, and school performance by taking into account the Organizational Climate factor. The objectives of this study (1) Describe the relationship between Transformational Leadership (X1) and Teacher Performance (Y), (2) Describe the Relationship between Compensation (X2) and Teacher Performance (Y), (3) Describe the Relationship between Organizational Climate (X1) with Teacher Performance (Y), and (4) Describe the Relationship between Transformational Leadership, Compensation, and Organizational Climate with Teacher Performance. This type of research is a field research with a sample of 80 people spread across 8 schools in the city of Mataram. The data retrieval instrument in this study uses a questionnaire as the main tool in data retrieval. Analysis of the data used is the Pearson Product Moment Correlation. The results of data analysis using the SPSS program showed a significant correlation between transformational leadership variables and teacher performance significance variables Sig.(2-tailed) 0,000<0,05. Significance value Sig. (2-tailed) between compensation variables with variable teacher performance is equal to $0.025<0.05$, meaning that there is a significant correlation between compensation variables with teacher performance variables. Significance value Sig. (2-tailed) between organizational climate variables with variable teacher performance of $0,000<0,05$, meaning that there is a significant correlation between organizational climate variables with teacher performance variables. Simultaneously there is a significant relationship between variables of transformational leadership, compensation, organizational climate and teacher performance.
\end{abstract}

Keywords: Transformational Leadership; Compensation; Organizational Climate; Teacher Performance

\section{Introduction}

In the Law of the Republic of Indonesia number 20 of 2003 concerning the National Education System, in chapter II article 2 states that national education is based on Pancasila and the 1945 Constitution of the Republic of Indonesia. Whereas article 3 states that the noble role of acting and functioning of national education develops capabilities and shapes national character and civilization that are dignified in order to educate the nation's life, understand and interpret aims to develop the potential of students to become human beings who believe and fear the Almighty God, have noble character, are 
healthy, knowledgeable, capable, creative, independent, and become democratic citizens and responsible. To develop the function of the national education, the teacher is the spearhead in realizing it.

The teacher has the task to educate, teach and train. Educating means continuing and developing life values, teaching means continuing and developing knowledge, training means developing skills in students. In carrying out these duties and responsibilities, a teacher is required to have certain abilities and skills. These abilities and skills are part of the teacher's professional competence. Competence is an ability that is absolutely possessed by the teacher so that his duties as an educator can be carried out well.

The application of teacher professional development in schools is the teacher's personal development to explore the potential within him. One of the characteristics of the success of a school that is assessed by the community is the achievement achieved by students every year. Schools that are considered good and considered quality if students have high achievements. The quality of education and graduates is often seen as dependent on the teacher's role in the management of the teaching components used in the teaching and learning process, which is his responsibility.

There are schools that have high student achievement, there are schools with ordinary student achievement scores, and there are also schools with poor student learning achievement. Schools with students who have outstanding achievements and schools with outstanding students are less required to improve the quality of their learning processes and outcomes.

Efforts to improve school quality are carried out by increasing discipline, motivation, job satisfaction, teacher performance, and school performance by taking into account the Organizational Climate factor. Because, according to Hepner, humans are prime movers, forming an organizational climate (Hepner, 2001: 197).

School organizational climate is one of the conceptual models of school culture and organization that can affect the success of students and teachers in forming goals (goal orientation), help improve self efficacy (self-efficacy which means a person's beliefs about the extent to which he is able to do tasks, achieve goals, and planning actions to achieve a goal), effort, perseverance, and student learning achievement, as well as teacher satisfaction for teaching success.

Thus, a conducive school organizational climate is a condition where the state of the school and its environment are safe, peaceful and pleasant for teaching and learning activities. Carver \& Sergiovanni (2006: 199), argues that the climate of school organizations in general was created, formed and channeled as a result of a school leadership's participatory transformational leadership.

The discourse on school progress will be more important if people give their attention to the principal's work, because the principal is a central figure of education; and the principal as a facilitator for the development of education. The principal is also the executor of a task that is full of hope and renewal. Packaging the noble ideals of our education indirectly also submitted to the principal. Likewise, the optimism of parents who are conditioned on the belief of sending their children to a particular school is nothing but because they depend on their ideals for the principal. In addition to the curriculum and rules realized by educators on coordination and autocracy.

According to Ishad, Yusrizal and Bahrun (2016: 33) explain the quality of school principals in leading schools very much determines the quality of school output. In carrying out its leadership functions, principals must conduct school management and guidance through various activities such as leadership or management activities. In this regard, principals have a significant influence on the quality of teaching practices and student achievement in school. In line with this theory Mulyasa (2005: 107) Leadership as the ability to move, influence, motivate, invite, direct, advise, guide, instruct, govern, 
prohibit, and even punish (if necessary) and foster with the intention that humans as a media management want to work in order to achieve administrative goals effectively and efficiently. To achieve effective and efficient goals in educational institutions can not be separated from the fulfillment of adequate compensation.

The compensation system contains very real symbols that communicate, behind their instrumental values, philosophy, attitudes and management desires. From the existing compensation system, the teacher or employee can know the cultural values that are embraced by management. The fact that cannot be denied is that someone who devotes himself to the world of education or the company is inseparable from the goal of earning a living. According to Alisyah Fitri (2017: 3) explaining compensation is very important for teachers, this is because compensation is a source of income for them and their families, besides providing compensation also affects the psychological conditions for the teacher himself in carrying out his duties as an educator.

Someone works to give time and energy to educational institutions and as a counter-achievement, agencies provide compensation or compensation whose forms can vary greatly. The system used by the organization in providing these benefits can affect work motivation and employee job satisfaction. Errors in applying the reward system will result in the emergence of demotivation and the absence of job satisfaction among workers. If this happens, it can cause a decrease in the performance of both workers and an agency. In reality, every organization applies a compensation system flexibly and freely in accordance with their respective conditions. Which system is appropriate to compensate workers in the hope of increasing performance and fostering job satisfaction.

Based on the description above, the author feels interested in raising it in this study with the title "The Relationship between Transformational Leadership, Compensation, and Organizational Climate with Teacher Performance of State High Schools in the Mataram City Region of NTB Province".

Starting from the direct observation of researchers in the field there are several problems faced by the State High Schools in the Mataram City Region as follows:

1. Organizational Climate. Structural dimensions especially job descriptions problems have not been applied as much as 75\% of high schools in the Mataram City Region. The Dimension of Responsibility, especially the problem of mutual support in completing the main tasks and functions of the teacher, has not been seen. They prioritize the ego centric, this is shown by only $15 \%$ of the high schools in the Mataram City Area that show a sense of mutual support among teachers in completing the main tasks and functions of the teacher. The dimensions of Sanctions and Rewards are far from what is expected so that the level of discipline, motivation, commitment to the main tasks and functions of the teacher is not optimal. This is indicated by only $10 \%$ of high schools in the City of Mataram that apply sanctions and rewards (Stick and Carott or Punishiment and Reward).

2. Transformational leadership among principals has not been implemented, in fact most still apply the bureaucratic and feudal leadership styles, namely $85 \%$ of high schools in the Mataram City Region. This is because during this time high school was anxious by the government. Whereas since the launch of the policy "READY VOCATIONAL SCHOOL" by the government indicates that the priority scale of education development in secondary education is more overlooked in vocational schools because there is hope that the output of SMK is prepared to enter the labor market or entrepreneurship. While high school output is more focused on the readiness to continue studying to college. 
3. Compensation. Within the limits of material compensation all refer to the APBD policy where the standard salary, allowances and other PNS teachers have been determined in accordance with existing provisions. However, non-material compensation is very dependent on each leader or the extent to which is very dependent on the existing organizational climate. That is, whether the organizational climate is conducive to the creation of non-material compensation for existing teachers in each of the high school education institutions. From the collected data, it can be seen that $65 \%$ of the number of SMA (PNS) Teachers in the Mataram City Area state that non-material compensation is less attention because the existing organizational climate is not conducive to the creation of adequate non-material compensation.

4. Commitment to the main tasks and functions of the teacher. The weak commitment of teachers to the main tasks and functions as educators arises because of the weak function of the principal's supervision and the lack of "Sanctions and Rewards" (Stick and Carott or Punishment and Reward). From the data collected, only 55\% of the number of high school teachers in the Mataram City area stated that they still had Commitments to their main tasks and functions as educators. The remaining $45 \%(100-55 \%)$ of the total number of high school teachers in the Mataram City area are limited to carrying out routine tasks in an effort to maintain their status as PNS Teachers. However, they lack optimal commitment in carrying out their main tasks and functions as professional educators.

5. The importance of teacher performance is not solely for the personal interests concerned, but also for the interests of the institution by improving education, leadership style, organizational climate and compensation. This can have a positive impact on teacher performance, especially in the city of Mataram because leadership style, organizational climate and good compensation for employees will be difficult for organizations to achieve optimal results.

Of the five problems mentioned above, this research is limited to Teacher Performance issues that are closely related to Transformational Leadership, Compensation, and Organizational Climate. Therefore, Teacher Performance is Dependent Variable (Endogen Variable). While Transformational Leadership, Compensation, and Organizational Climate as Independent Variables (Exogen Variable). Based on the description of the background, identification and limitations of the problem, the formulation of the research problem is as follows:

1. Is there a relationship between Transformational Leadership and Teacher Performance?

2. Is there a relationship between compensation and teacher performance?

3. Is there a relationship between Organizational Climate and Teacher Performance?

4. Is there a relationship between Transformational Leadership, Compensation, and Organizational Climate with Teacher Performance? 


\section{Theoretical Study}

\section{Leadership}

Leadership is a spirit that is the center of the organization's movement to achieve goals. Leadership related to school principals in increasing the opportunity to hold meetings effectively with teachers in conducive situations. The behavior of principals must be able to encourage the performance of the teachers by showing a sense of friendliness, closeness, and full consideration of the teachers, both as individuals and as groups. Instrumental behavior is tasks that are oriented and directly clarified in roles. According to Ivancevich (2004: 327-329), leadership is an effort to influence others through interpersonal communication to achieve group goals. In essence, leadership is a process of influencing others in achieving their stated goals.

This understanding is emphasized in the sentence affecting other people in which there are elements of relations, processes, and activities. To achieve goals with a leader need to use various ways. These methods are usually manifested by giving instructions, directing, and fostering to carry out various activities related to their duties and responsibilities (J.C. Brigham, 2004: 345).

Seckler and Catherine (2002: 175-177) states that leadership is the process of influencing and mobilizing and encouraging work to people to work together in order to realize certain purposes. Whereas according to Kouze and Posner (2004: 345), what is meant by leadership is a person's skills and abilities in influencing the behavior of others, both those with a higher level and lower than that, in thinking and acting so that behavior that may be individualistic and egocentric changed to organizational.

From the notions of leadership it appears that leadership is essentially an effort to influence and mobilize other people to work together in order to achieve a predetermined common goal. Discourse about the progress of the school will be more important if people give attention to the gait of the principal, because the head the school is the central figure of education; and the principal as a facilitator for the development of education. The principal is also the executor of a task that is full of hope and renewal. Packaging the noble ideals of our education indirectly also submitted to the principal. Likewise, the optimism of parents who are conditioned on the belief of sending their children to a particular school is nothing but because they depend on their ideals for the principal. In addition to the curriculum and rules realized by educators on coordination and autocracy.

\section{Compensation}

One of the goals of the organization to gain profit is the cost of employees as well as other types of costs, which are components of organizational costs that need to be controlled in the context of minimizing costs so that optimal high efficiency activities can be achieved. Meanwhile, from the point of view, the employee considers that remuneration can be seen as a means of fulfilling various needs of his life. According to Nurzaman (2014: 179) said compensation is something received by employees as a reward for their achievements in carrying out their duties.

According to Flippo (2006: 146), compensation programs are designed to do three things, namely: 1) To attract capable teachers in the learning process, 2) To motivate teachers to achieve high achievements, and 3) To create a long service period. The compensation program is also important for the organization because it reflects the organization's efforts to maintain its human resources. In addition, compensation (in the form of wages and other remuneration) is often the largest and most important cost component. 
Related to compensation Hasibuan (2003: 118) suggests as follows:

"Compensation is all income in the form of money, direct or indirect goods received by employees in return for services provided to the organization. Compensation is in the form of money, meaning that compensation is paid in cash for the employee concerned. Compensation in the form of goods, meaning compensation is paid for with goods. For example, compensation is paid $10 \%$ of the production produced. In West Java, rice harvesters pay $10 \%$ of the yield of the rice they harvest".

According to Mulyasa (2006: 156) found that compensation is remuneration for services provided by education and school services to education personnel, who can be assessed with money and have a tendency to be given regularly.

Based on the description, the following can be stated that in principle, the provision of compensation is the result of the sale of personnel to the organization. However, in this case it also contains the notion that the employees have given all their work capabilities to the organization so that the organization naturally respects the work of the employee by giving compensation or equal compensation to the employee.

From various opinions about compensation raised by experts in human resource management, the researcher draws a synthesis that compensation or reward is all forms of payment provided by the company to employees as remuneration for the implementation of duties or employee contributions to the company, both given regular and situational. Compensation is an award that is given to teaching staff in a fair and decent manner, which is intended for teacher work performance that has been issued for the achievement of school goals.

\section{Organizational Climate}

Organization as a social system, its journey is always influenced by its environment, both internal and external. The perceived environment has long been considered to have interacted with the characteristics of individual workers and determined their behavior. This is what is often said to be an Organizational Climate. Explicitly the organizational climate can be interpreted as a broad form of the perceptions of educators in their educational work environment, which is influenced by formal organizations, informal organizations, individual personalities and leadership of their leaders.

Organization is a pattern of cooperation between people involved in activities that are interconnected to achieve certain goals (Wexley and Yukl, 1980). In line with this theory Robert G. Owens (2001: 197), defines organizational climate as the study of individual perceptions of various aspects of the organization's environment. Davis and Newstrom (2005: 315), suggested Organizational Climate as "The human environment within an organization's employees do their work". (The climate of the organization is that which concerns all the environments that exist or are faced by humans in an organization where they carry out their work).

Taguiri and Litwin (2007: 119), define organizational climate as the quality of the organization's internal environment which is relatively ongoing, experienced by members of the organization, influencing their behavior and can be described in terms of a set of characteristics or characteristics of the organization. 
Wirawan (2008: 78), organizational climate as a concept that describes the subjective nature or quality of the organization's environment. The elements can be perceived and experienced by members of the organization.

James L. Gibson et all. (2002: 173), argues that the organizational climate as:

"climate is a set of equipment from a work environment that is felt directly or indirectly by employees who work in this environment and thinks it will be a major force that influences their behavior at work"

B. H Gilmer (2001: 197), said that organizational climate is a characteristic that distinguishes one organization from another organization and influences people in the organization. Furthermore, (Steers and Porter, 2003: 213) say that a particular organizational climate is the climate seen by workers, not always the actual climate and climate that arises in the organization are the main factors that determine worker behavior.

Based on the theories stated above, it means that the climate of the organization includes several elements that can make an organization imbued by all its members.

\section{Teacher Performance}

Mangkunegara (2008) defines that performance is the work of quality and quantity achieved by an employee in carrying out his duties in accordance with the responsibilities given to him. While Sturman quoted Hendrawan (2006) argues that performance is a multinational construct that is very complex, with many differences in meaning depending on who is evaluating, how it is evaluated, and what aspects are evaluated.

Sulistiyani and Rosyidah (2003) also suggest that performance is a result of work achieved by someone in carrying out tasks assigned to him based on skills, experience, and sincerity and time. Sulitiyani and Rosyidah state that a person's performance is a combination of ability, effort and opportunity that can be judged by his work.

Teacher performance is basically a performance or performance that can be seen and measured based on certain standards, or competency criteria that must be possessed by each teacher, namely carrying out their duties as educators. The teacher's performance standards relate to the quality of the teacher in carrying out his professional duties, the teacher is obliged to plan learning, carry out the quality learning process, and assess and evaluate learning outcomes. In addition, the teacher is also obliged to improve and develop academic qualifications and competencies on an ongoing basis in line with the development of science, technology and art. For students, the teacher is also obliged to act objectively and not discriminatively on the basis of consideration of gender, religion, ethnicity, race, and certain physical conditions, or family background, and the socio-economic status of students in learning. With regard to the applicable regulations, the teacher is obliged to uphold the laws and regulations, the law, and the teacher's code of ethics, as well as religious and ethical values, and maintain and foster national unity. (Law of Teachers and Lecturers No. 14 of 2005, Article 20). 


\section{Method}

This study aims to obtain valid, reliable, reliable data, facts, and information about: 1 . Relationship between Transformational Leadership and Teacher Performance; 2. The relationship between compensation and teacher performance; 3. Relationship between Organizational Climate and Teacher Performance; and 4. Relationship between Transformational Leadership, Compensation, and School Climate with Teacher Performance.

The research was conducted in the city of Mataram. Data collection for trial data on research and research instruments was carried out by sending research instruments to all public high schools in the city of Mataram. The study was conducted in February to the end of May 2019. The research method used was a survey method with correlational techniques. This research is a field research (Field Research) where the findings in the field as primary data (primary data) which is the main material to be processed and analyzed. this research is descriptive analysis.

The population in this study were all Teachers (PNS) in 8 (eight) Public High Schools in the Mataram City Region totaling 353 teachers (NTB Provincial Statistics Agency, 2013, p. 157). The research sample was teachers (PNS) at 8 (eight) Mataram City Public High Schools, which were taken by a proportional random sampling technique of 80 teachers.

The research instrument used in this study is an instrument designed based on conceptual definitions, operational definitions and research instrument grids. For teacher performance variables consisting of 40 items statement, transformational leadership variable consists of 31 items statement, compensation variable consists of 32 items statement, and organizational climate variable consists of 35 points statement. All items have been tested for validity and control.

\section{Research Result}

\section{Description of Data Research}

In this study the data was obtained by delivering the questionnaire directly to the respondents in each of the public high schools in the city of Mataram. The research was conducted on 8 Mataram City Public High Schools, namely 1 Public High School, 2 Public High Schools, 3 Public High Schools, 4 Public High Schools, 5 Public High Schools, 6 Public High Schools, 7 Public High Schools, and 8 Public High Schools with 10 respondents each school.

In distributing questionnaires to 8 schools in the city of Mataram conducted by distributing 80 questionnaires. Each questionnaire is given to the respondent and it is expected that the respondent can fill in the statements submitted on the questionnaire according to the actual situation. Of the 80 questionnaires distributed to 8 public high schools in the city of Mataram, all of them can be processed into data that is useful for the continuation of this research. Questionnaires distributed to respondents, with distribution of distribution are presented in Table 1 below. 
Table 1. Distribution of Distribution of Questionnaires

\begin{tabular}{|l|l|l|l|}
\hline No & School Name & $\begin{array}{l}\text { Kuisioner disebar } \\
\left.\text { (Variable } \mathbf{X}_{\mathbf{1}}, \mathbf{X}_{\mathbf{2}}, \mathbf{X}_{\mathbf{3}}, \mathbf{Y}\right)\end{array}$ & $\begin{array}{l}\text { Return Questionnaire } \\
\left(\text { Variable } \mathbf{X}_{\mathbf{1}}, \mathbf{X}_{\mathbf{2}}, \mathbf{X}_{\mathbf{3}}, \mathbf{Y}\right)\end{array}$ \\
\hline 1 & Public High School 1 & 40 & 40 \\
\hline 2 & Public High School 2 & 40 & 40 \\
\hline 3 & Public High School 3 & 40 & 40 \\
\hline 4 & Public High School 4 & 40 & 40 \\
\hline 5 & Public High School 5 & 40 & 40 \\
\hline 6 & Public High School 6 & 40 & 40 \\
\hline 7 & Public High School 7 & 40 & 40 \\
\hline 8 & Public High School 8 & 40 & 40 \\
\hline Count & 320 & 320 \\
\hline
\end{tabular}

Based on the table above shows that each variable consists of 10 questionnaires given to 10 teachers in each school. The number of questionnaires given is the same as the number of questionnaires returned by each school, meaning that all research samples filled out and returned questionnaires distributed by researchers.

\section{Respondent's description}

Of the 320 questionnaires, the general description of which can be seen in table 4.2. 52 respondents, $65 \%$ and 28 respondents or $35 \%$ women, meaning that there are male respondents. In terms of age, there were 3 respondents who were in the range of less than 25 years or $3.75 \%, 13$ respondents aged 25 to 30 years or around $16.25 \%$, respondents aged between 31 and 40 years were 49 or $61.25 \%$, as for respondents or between respondents aged 31 to 40 years or $22.5 \%$.

Judging from the tenure of respondents in this study obtained 25 respondents or $31.25 \%$ with a range of work periods of 2 to 3 years, for work periods of more than 4 years as many as 65 respondents or $68.75 \%$, and there were no respondents with less years of service from 1 year. In terms of education, respondents with a Bachelor level (S1) education were 71 respondents or $88.75 \%$, for respondents with postgraduate education (S2) as many as 9 respondents or $11.25 \%$ and no respondent in this study with educational levels S3.

Based on respondance description, it can be concluded that the respondents who were the most were seen from the sex of men as much as $65 \%$, viewed from an age perspective dominated by respondents ranging in age from 31 to 40 years as many as $61.25 \%$. Viewed from the respondent's working period the most in this study was dominated by respondents with a work period of more than 4 years as much as $68.75 \%$. Meanwhile, in terms of education, it was dominated by respondents with a Bachelor's level of education (S1) of $88.75 \%$. 
Descriptive Analysis Transformational Leadership Variables, Compensation, Organizational Climate and Teacher Performance

From the results of questionnaires on transformational leadership variables, compensation, organizational climate and teacher performance to 80 teachers in Public High Schools in Mataram City spread out in eight schools such as the following table.

Table 2 Descriptive Statistics Test

\begin{tabular}{|l|l|l|l|l|l|}
\hline No. & Criteria & X1 & X2 & X3 & Y \\
\hline 1 & Missing & 0 & 0 & 0 & \\
\hline 2 & Valid & 80 & 80 & 80 & 80 \\
\hline 3 & Mean & 105.48 & 103.91 & 96.00 & 103.05 \\
\hline 4 & Median & 106.00 & 102.50 & 95.50 & 101.00 \\
\hline 5 & Mode & 99 & 100 & 99 & 100 \\
\hline 6 & Std. Deviation & 11.961 & 14.617 & 11.103 & 14.329 \\
\hline 7 & Minimum & 80 & 79 & 73 & 70 \\
\hline 8 & Maximum & 129 & 145 & 123 & 135 \\
\hline
\end{tabular}

Based on the table above can be explained in the form of instagram for each variable. Data related to transformation leadership variables are also presented in the following histogram. The respondent criteria in this study were subject teachers who had at least 2 years of teaching experience.

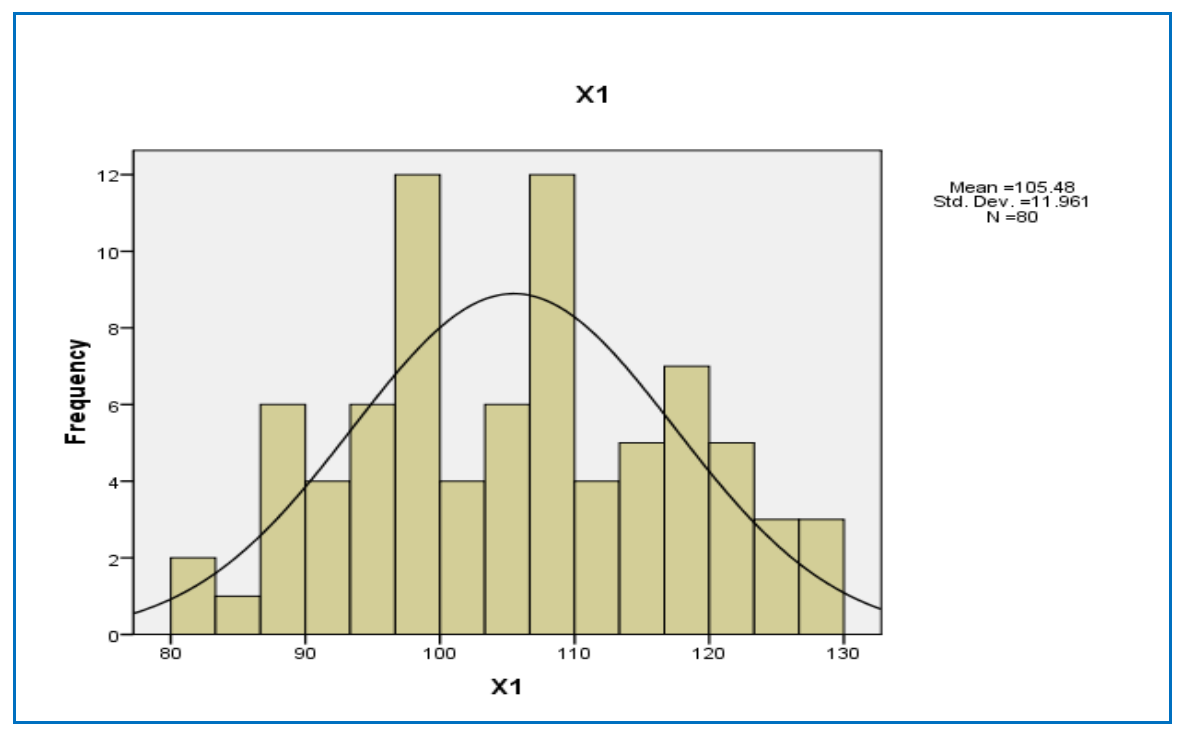

Figure 1. Descriptive Test of Statistics on Variable Transformational Leadership

Based on the picture above it can be concluded that transformation leadership has a mean value of 105.48 and a median value of 106 . The mode of the transformation leadership variable is 99 with a maximum value and a minimum of 129 and 80, there is a default of 11.961. Discretionary tests of compensation variable statistics can also be seen in the following histogram. 


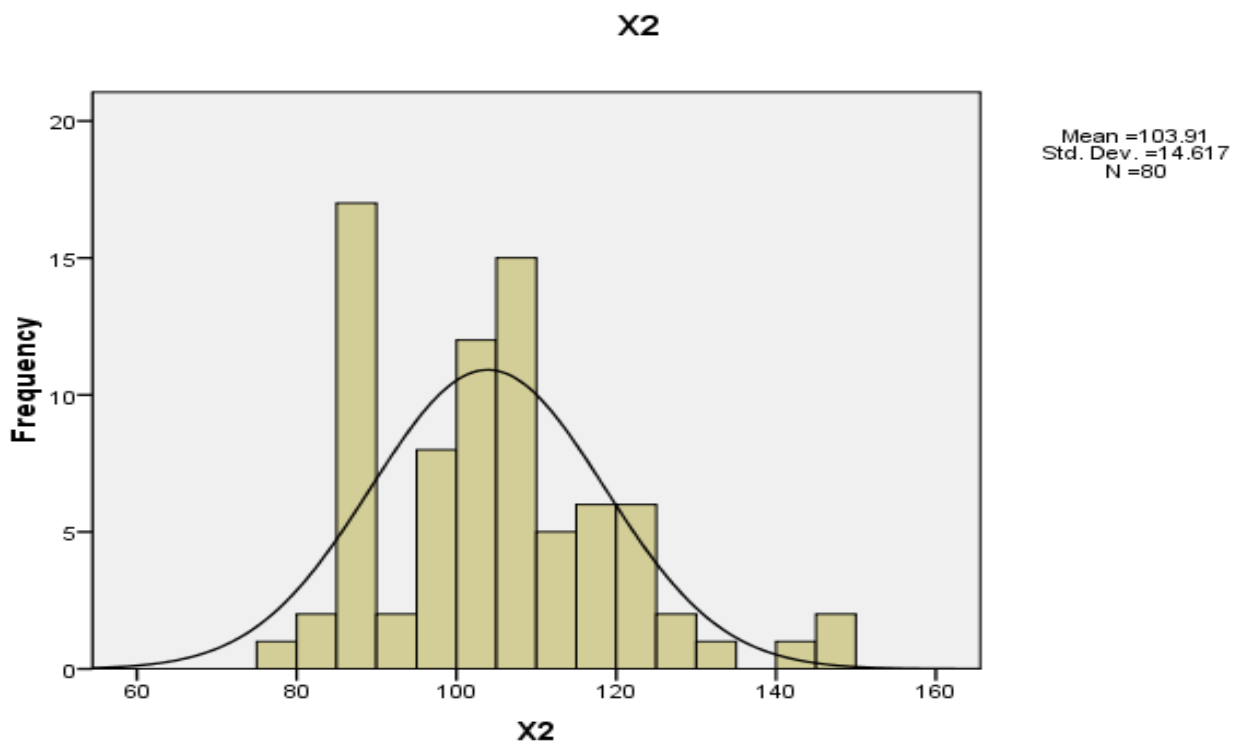

Figure 2 Descriptive Test of Varabel Compensation Statistics

For descriptive analysis of the compensation variable statistics on the statistics table above shows the mean value of 103.91 and median 102.50 with mode 100 . The maximum value is 145 and drink 79 with a standard deviation of 79 . Discrete data statistics on organizational climate variables are presented in the following histogram.

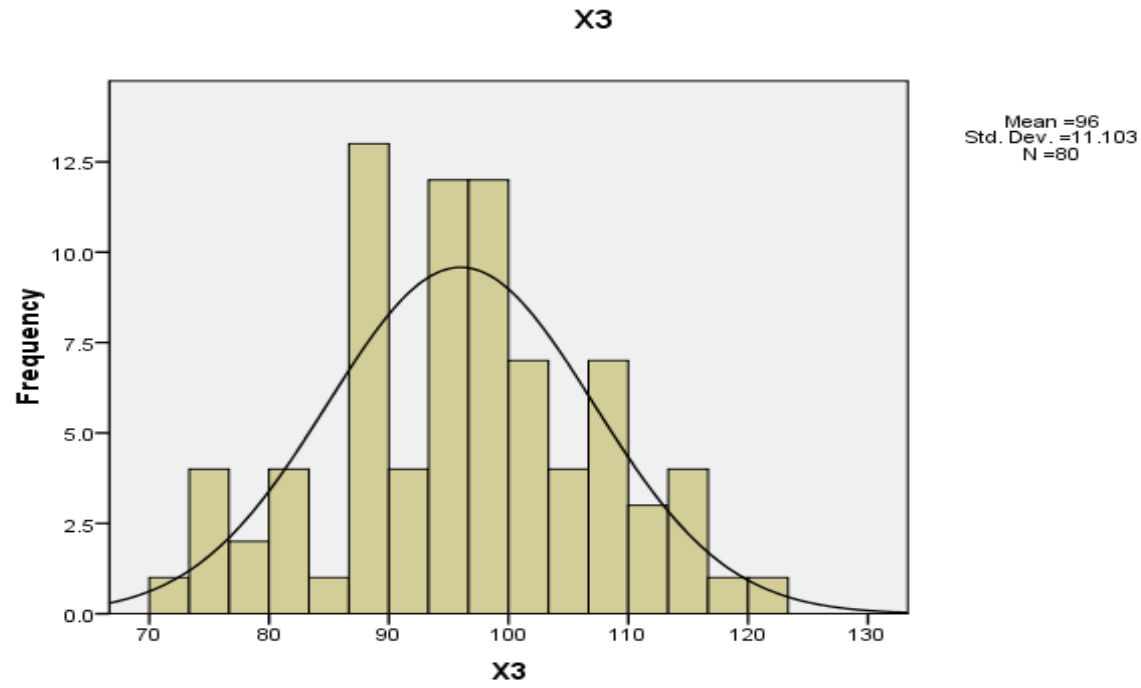

Figure 3 Descriptive Test of Varabel Organizational Climate Statistics

Based on the results of descriptive analysis of variable Compensation using the SPSS program the mean values were 96 and median 95.50 with the mode values 99 . The maximum and minimum values of compensation variables were 73 and 123 with a standard deviation of 11.103 . The results of the descriptive analysis of the teacher performance variables are also presented in the following histogram. 


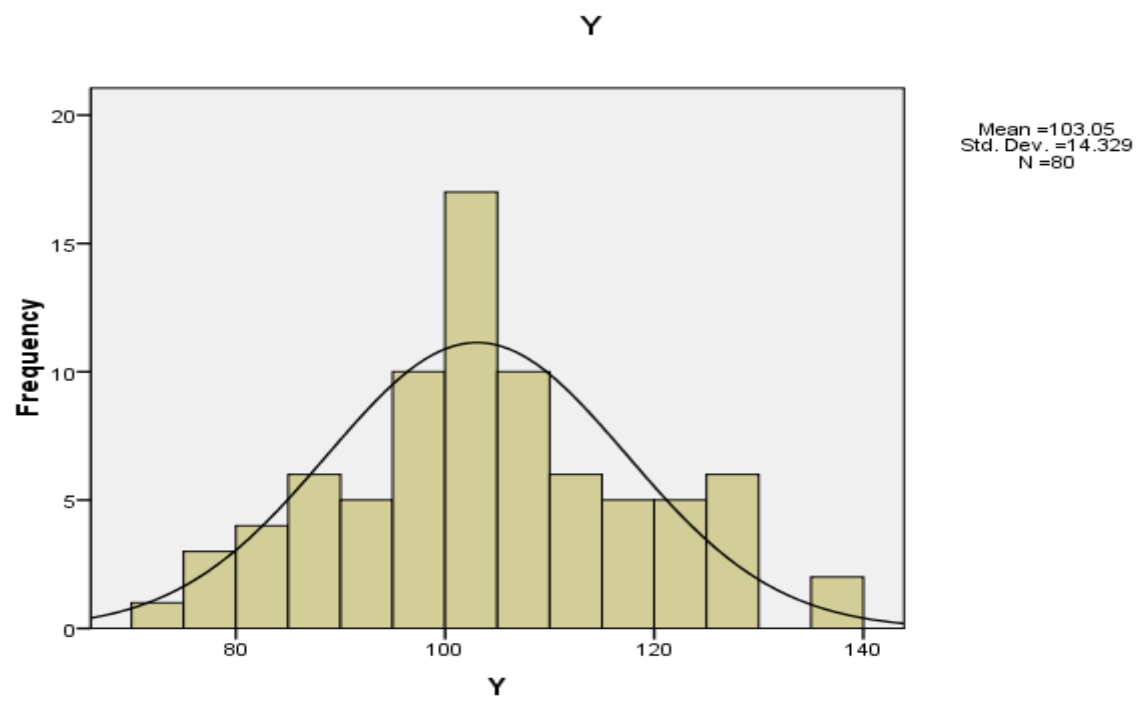

Figure 4.4 Descriptive Images of Variable Teacher Performance

The results of descriptive statistical analysis for teacher performance variables using the SPSS program obtained a mean value of 103.05 and a median value of 101 with a mode value of 100 . Maximum and minimum values of teacher performance variables were 135 and 70 respectively with a standard deviation value of 14,329 .

\section{Relationship between Transformational Leadership and Teacher Performance}

The Analysis results relationship between transformational leadership and teacher performance of as in the following table 3 .

Tabel 3. Relationship between Transformational Leadership and Teacher Performance

\begin{tabular}{|l|l|r|r|}
\hline & & Transformational Leadership & \multicolumn{1}{c|}{$\begin{array}{c}\text { Teacher } \\
\text { Performance }\end{array}$} \\
\hline \multirow{5}{*}{ Transformational Leadership } & Pearson Correlation & 1 & $.384^{* *}$ \\
\cline { 2 - 4 } & Sig. (2-tailed) & & .000 \\
\cline { 2 - 4 } & $\mathrm{N}$ & 80 & 80 \\
\hline \multirow{2}{*}{ Teacher Performance } & Pearson Correlation & $.384^{* *}$ & 1 \\
\cline { 2 - 4 } & Sig. (2-tailed) & .000 & 80 \\
\cline { 2 - 4 } & $\mathrm{N}$ & 80 & \\
\hline
\end{tabular}

Table 3 Test Results Correlation of Transformational Leadership Variables with Teacher Performance Based on the Correlations table above the significance value of Sig. (2-tailed) between transformational leadership variables with variable teacher performance of $0,000<0,05$, which means there is a significant correlation between transformational leadership variables with teacher performance variables. 


\section{The Relationship between Compensation and Teacher Performance}

The Analysis results of relationship between compensation and teacher performance as in the following table 4.

Table 4 Test Results Correlation of Compensation Variables with Teacher Performance

\begin{tabular}{|l|l|r|r|}
\hline \multirow{4}{*}{ Compensation } & Pearson Correlation & Compensation & \multicolumn{1}{|c|}{ Teacher Performance } \\
\cline { 2 - 4 } & Sig. (2-tailed) & 1 & $.251^{*}$ \\
\cline { 2 - 4 } & $\mathrm{N}$ & 80 & .025 \\
\hline $\begin{array}{l}\text { Teacher } \\
\text { Performance }\end{array}$ & Pearson Correlation & $.251^{*}$ & 80 \\
\cline { 2 - 4 } & Sig. (2-tailed) & .025 & 1 \\
\cline { 2 - 4 } & $\mathrm{N}$ & 80 & 80 \\
\hline
\end{tabular}

Based on the Correlations table above the significance value of Sig. (2-tailed) between compensation variables with variable teacher performance is $0.025<0.05$, which means there is a significant correlation between compensation variables with teacher performance variables.

\section{Relationship between Organizational Climate and Teacher Performance}

The purpose of the correlation test carried out on the variable Organizational climate with teacher performance variables is to see whether the two variables have a significant relationship or not. Analysis results as in the following table.

Table 5. Test Results Correlation of Compensation Variables with Teacher Performance

\begin{tabular}{|l|l|r|r|}
\hline \multirow{3}{*}{ Organizational Climate } & & Organizational Climate & Teacher Performance \\
\cline { 2 - 4 } & Pearson Correlation & 1 & $.554^{* *}$ \\
\cline { 2 - 4 } & Sig. (2-tailed) & & .000 \\
\cline { 2 - 4 } Teacher Performance & $\mathrm{N}$ & 80 & 80 \\
& Pearson Correlation & $.554^{* *}$ & 1 \\
\cline { 2 - 4 } & Sig. (2-tailed) & .000 & 80 \\
\cline { 2 - 4 } & $\mathrm{N}$ & 80 & \\
\hline
\end{tabular}

Based on the Correlations table above the significance value of Sig. (2-tailed) between organizational climate variables with variable teacher performance of $0,000<0,05$, which means there is a significant correlation between organizational climate variables with teacher performance variables. 
The relationship between Transformational Leadership, Compensation and Organizational Climate together with Teacher Performance

This test was conducted to see whether all the independent variables (Transformational Leadership, Compensation, and Organizational Climate) with the dependent variable (Teacher Performance). Analysis results as in the following table.

Table 6. Simultaneous Test Results of Variable Transformational Leadership, Compensation, and Organizational Climate with Teacher Performance variable.

\begin{tabular}{|c|c|c|c|c|c|}
\hline & & $\begin{array}{c}\text { Teacher } \\
\text { Performance }\end{array}$ & $\begin{array}{c}\text { Transformation } \\
\text { al Leadership }\end{array}$ & $\underset{\text { tion }}{\text { Compensa }}$ & $\begin{array}{l}\text { Organizational } \\
\text { Climate }\end{array}$ \\
\hline \multirow[t]{3}{*}{ Teacher Performance } & Pearson Correlation & 1 & $.384^{* *}$ & $.251^{*}$ & $.521^{* *}$ \\
\hline & Sig. (2-tailed) & & .000 & .025 & .000 \\
\hline & $\mathrm{N}$ & 80 & 80 & 80 & 80 \\
\hline \multirow{3}{*}{$\begin{array}{l}\text { Transformational } \\
\text { Leadership }\end{array}$} & Pearson Correlation & $.384^{* *}$ & 1 & $.225^{*}$ & $.231^{*}$ \\
\hline & Sig. (2-tailed) & .000 & & .045 & .039 \\
\hline & $\mathrm{N}$ & 80 & 80 & 80 & 80 \\
\hline \multirow[t]{3}{*}{ Compensation } & Pearson Correlation & $.251^{*}$ & $.225^{*}$ & 1 & $.266^{*}$ \\
\hline & Sig. (2-tailed) & .025 & .045 & & .017 \\
\hline & $\mathrm{N}$ & 80 & 80 & 80 & 80 \\
\hline \multirow[t]{3}{*}{ Organizational Climate } & Pearson Correlation & $.521^{* * *}$ & $.231^{*}$ & $.266^{*}$ & 1 \\
\hline & Sig. (2-tailed) & .000 & .039 & .017 & \\
\hline & $\mathrm{N}$ & 80 & 80 & 80 & 80 \\
\hline \multicolumn{6}{|c|}{ **. Correlation is significant at the 0.01 level (2-tailed). } \\
\hline \multicolumn{3}{|c|}{ *. Correlation is significant at the 0.05 level (2-tailed). } & & & \\
\hline
\end{tabular}

Based on the table above it can be concluded that:

- The partial correlation coefficient between $\mathrm{Y}$ and $\mathrm{X}_{1}$ is 0,000 . The relationship between $\mathrm{X}_{1}$ and $\mathrm{Y}$ when the other independent variables are constant is strong.

- The partial correlation coefficient between $\mathrm{Y}$ and $\mathrm{X}_{2}$ is 0.025 . The relationship between $\mathrm{X}_{2}$ and $\mathrm{Y}$ when the other independent variables are constant is strong.

- The partial correlation coefficient between $\mathrm{Y}$ and $\mathrm{X}_{3}$ is 0,000 . The relationship between $\mathrm{X}_{3}$ and $\mathrm{Y}$ when the other independent variables are constant is strong. 


\section{Conclusions}

Based on the results of the research this study can be conclude that:

1. There is a significant correlation between transformational leadership variables and teacher performance variables significance Sig. (2-tailed) $0,000<0,05$.

2. Significance value Sig. (2-tailed) between compensation variables with variable teacher performance is equal to $0.025<0.05$, meaning that there is a significant correlation between compensation variables with teacher performance variables.

3. Significance value Sig. (2-tailed) between organizational climate variables with variable teacher performance of $0,000<0,05$, meaning that there is a significant correlation between organizational climate variables with teacher performance variables.

4. Simultaneously there is a significant relationship between transfoemational leadership variables, compensation, organizational climate with teacher performance.

5. The partial correlation coefficient between $Y$ and $X_{1}$ is 0,000 . The relationship between $X_{1}$ and $Y$ when the other independent variables are constant is strong.

6. The partial correlation coefficient between $\mathrm{Y}$ and $\mathrm{X}_{2}$ is 0.025 . The relationship between $\mathrm{X}_{2}$ and $\mathrm{Y}$ when the other independent variables are constant is strong.

7. The partial correlation coefficient between $\mathrm{Y}$ and $\mathrm{X}_{3}$ is 0,000 . The relationship between $\mathrm{X}_{3}$ and $\mathrm{Y}$ when the other independent variables are constant is strong.

\section{Bibliography}

Antonius, P. 1995. Payroll Services: Description of Salary and Implementation Scale Design. Jakarta: Grasindo.

Anwar, M.I and Hidayat A, Y. 2008. Educational Administration, Theory, Concepts and Issues. Bandung: UPI Bandung.

Arikunto, S. 2006. Research Procedures A Practice Approach. Jakarta: Rineka Cipta.

Asnawi, S. 2005. Application of Psychology in Human Resource Management. Jakarta, Ghalia Indonesia.

Awaludin, E. 2005. Analysis of the Effect of Leadership and Work Motivation on Organizational Climate PT. Bank Negara Indonesia (PT. Bank BNI) Sudirman Branch Office. Thesis Master of Management at Airlangga University: not published.

Azwar. S. 2003. Human Attitudes: Theory and Measurement. Yogyakarta: Faculty of Economics, University of Gajah Mada. 
Bustam, A. M. 2006. Effects of Leadership Compensation and Managerial Ability on Organizational Climate PT. Indosat Tbk. Thesis. Master of Management. Denpasar: Udayana University.

Bass, B.M and Avolio, B. J. 2000. The Implications of Transactional and Transformational Leadership for Individual, Team, and Organizational Development. Michigan. Research in Michigan Organizational Change and Development of University. Vol. 4.

Boedianto. 2005. Planning and Organizing Workforce Training. Yogyakarta: Andi Offset.

Carver, F. D and Sergiovanni, T. J. 2006. Organizations and Human Behavior: Focus on Schools. 8th edition. Columbia: McGrawHill.

Davis, K and Newstrom, J. W. 1995. Human Behavior at Work: Organizational Behavior; Interpreting by: Agus Dharma, SH., M. Ed. Erlangga: Jakarta.

Djaali, M. P and Ramly. 2000. Measurements in the Field of Education. Jakarta: Jakarta State University.

Danim, S. 2002. Educational Innovation in an Effort to Increase the Professionalism of Educational Personnel. Jakarta: Loyal Library.

Danim, S. 2002. Become a Learning Community: Transformational Leadership in Learning Community Organizations, Jakarta: Earth Literacy.

Fred Luthans. 2007. Corporate Culture: Challenge To Excellence. Jakarta. Elex Media Komputindo.

Edwin, B. F. 2006. Personnel Management ... New York Mc Graw Hill. Beginning in 2006.Becoming a Professional Teacher. Bandung: PT. Youth Rosda Karya.

French and Raven. 2008. Leadership: The Key Concepts. Boston: Mc Graw Hill.

Ghozali, I. 2007. Application of Multivariate Analysis with the SPSS Program. Semarang: Diponegoro University.

Hadi, S. 2016. "The Effect of Organizational Climate and Teaching Motivation on Professional Performance of Teachers of High School, Vocational School, MA Muhammadiyah in Kudus Regency". Journal. Quality. 4, (1).

Handoko, H. T. 1999. Personnel Management and Human Resources. BPFE: Yogyakarta. 13th print.

Handoko, H. T 2008. Management, Personnel and Human Resources. Yogyakarta: Faculty of Economics, University of Gajah Mada. edition 2.

Hepner, H. W. 2001. Perceptive Management and Supervision: Insights For Working With People. Michigan: Prentice-Hall.

Ivancevich, J. M. I. 2004. Human Resources Management. New York. Mc Graw Hill.

Ivancevich, J. M. I. 1992. Human Resource Management. Richard D Irwin, Inc., 1992.

James L. G et al. 2002. Organizations: Behavior, Structure, Processes. New York. Mc Graw Hill. 
James, G. M. 2004. Leadership. New York: Harper \& Row.

Kamaruddin. 2001. Analysis of the Modern Management Organization. Jakarta: Rajawali.

Kasim, A. 1993. Measurement of Effectiveness in Organizations. Jakarta: Institute of Publishers of the Faculty of Economics, University of Indonesia.

Kasim, A. 2006. Decision Making Theory. Jakarta: Institute of Publishers of the Faculty of Economics, University of Indonesia.

Kenneth, N.W and Gary, A. 2003. Organizational Behavior and Personnel Psychology. Jakarta. PT Rineka Cipta.

Koster, W. 2008. KTSP Management: Theory, Models, and Applications. Jakarta. Grasindo.

Kouze and Posner. 2004. The Leadership Challenge. New Jersey: Prentice Hall International Edition.

King, B. T. et al. 2007. Managerial Control and Organizational Democracy. Houston: V. H. Winston.

Litwin, G. H. and Stringer, R. A. 2004. Fundamentals of Organizational Behavior An Applied Perspective. Columbia: Pergamon Press.

Lumbatoruan, Magdalena. 2002. Encyclopedia of Economics, Business and Management. Bandung: STBA YAPARI ABA.

Malo, M. 2002. Community Research Methods. Jakarta: PAU FISIP UI.

Mathis, J. 2000. Human Resource Management. Jakarta: Salemba Empat.

Milkovich, G. T and Newman, J. M. 1999. Compensation. The McGraw-Hill Companies, Inc.

Mitrani, A. 2005. Human Resource Management Based on Competence. Jakarta: Main Library.

Moedjiarto. 2001. Development of School Service Programs, Malang: Malang State University.

Moedjiarto. 2004. Teacher Effectiveness Improvement Program. Poor. Malang State University.

Mulyasa. 2005. School Based Management. Bandung: Youth Rosdakarya.

Muwarni, S. 2008. Applied Statistics. Jakarta: UHAMKA.

Nawawi, H. H. 2000. Strategic Management of Non-Profit Organizations in Government. Yogyakarta: Gadjah Mada University Press.

Owens, R. G. 2001. Organizational Behavior in Schools 5th. Edition. Michigan. Prentice-Hall.

Putrawan, M. 2000. Testing Hypotheses in Social Research. Jakarta: Rineka Cipta.

Ranupanjodo, H and Husnan, S. 2002. Personnel Management. Yogyakarta: BPFE.

Robbins, S. P. 2008.Organizational Behavior. New Jersey Prentice Hall. 
Robbins, S. P. 2008. 12th Edition Organizational Behavior. Jakarta: Salemba Empat.

Sanyoto, M. Ashar. 2006. Industrial and Organizational Psychology. Jakarta: UI Press.

Sayle, L and Strauss, G. 2005, Working Leader. New York: The Free Press.

Seckler and Catherine. 2002, Empower Your Human Resources. New York: McGrawHill International Edition.

Simamora, H. 1995. Human Resource Management: Publishing Section STIE YKPN: 1st Edition, first printing: Yogyakarta.

Singarimbun, M and Efendi, S. 2004, Survey Research Methods. Jakarta: LP3ES.

Steers, R, M. and Porter, L, W. 2003. Motivation and Work Behavior. New Jersey: McGraw-Hill.

Sudarmanto, R. G. 2007. Multiple Linear Regression Analysis with SPSS. Jakarta: Graha Ilmu.

Sugiyono. 2007. Statistics for Research. Bandung: Alpahbet.

Supranto. J. 2007. Business Research Methods. Jakarta: Rineka Cipta.

Taguiri, R and Litwin, G. H. 2007. Managing Human Resources. 4th. Edition. California: PrenticeHall.

Pitri, A. 2017. "Effects of Compensation on teacher performance in 3 Batusangkar Public Middle Schools". Journal of Management, Leadership, and Educational Supervision, 2, (1).

Wahyosumijo. 2006. Leadership Tips in Theory and Practice. Bandung: Youth Rosda Karya.

Hero. 2008. Organizational Culture and Climate. Jakarta: Salemba Empat.

Yukl, G. 2004. Leadership in Organizations. Jakarta: Erlangga.

\section{Copyrights}

Copyright for this article is retained by the author(s), with first publication rights granted to the journal.

This is an open-access article distributed under the terms and conditions of the Creative Commons Attribution license (http://creativecommons.org/licenses/by/4.0/). 